\title{
Developing Critical
}

Languaculture Pedagogies

in Higher Education 


\section{LANGUAGES FOR INTERCULTURAL COMMUNICATION AND EDUCATION}

Series Editors: Michael Byram, University of Durham, UK and Alison Phipps, University of Glasgow, UK

The overall aim of this series is to publish books which will ultimately inform learning and teaching, but whose primary focus is on the analysis of intercultural relationships, whether in textual form or in people's experience. There will also be books which deal directly with pedagogy, with the relationships between language learning and cultural learning, between processes inside the classroom and beyond. They will all have in common a concern with the relationship between language and culture, and the development of intercultural communicative competence.

Full details of all the books in this series and of all our other publications can be found on http://www.multilingual-matters.com, or by writing to Multilingual Matters, St Nicholas House, 31-34 High Street, Bristol BS1 2AW, UK. 
Developing Critical

Languaculture Pedagogies

in Higher Education

Theory and Practice

Adriana Raquel Díaz 


\section{Library of Congress Cataloging in Publication Data}

Developing Critical Languaculture Pedagogies in Higher Education: Theory and Practice/ Adriana Raquel Diaz.

Languages for Intercultural Communication and Education: 25

Includes bibliographical references and index.

1. Language and languages_-Study and teaching (Higher)—Case studies. 2. Language teachers-Training of. 3. Language and culture-Study and teaching--Case studies.

I. Title.

P53.755.D53 2013

418.0071'1-dc23 2013022860

\section{British Library Cataloguing in Publication Data}

A catalogue entry for this book is available from the British Library.

ISBN-13: 978-1-78309-035-8 (hbk)

ISBN-13: 978-1-78309-034-1 (pbk)

\section{Multilingual Matters}

UK: St Nicholas House, 31-34 High Street, Bristol BS1 2AW, UK.

USA: UTP, 2250 Military Road, Tonawanda, NY 14150, USA.

Canada: UTP, 5201 Dufferin Street, North York, Ontario M3H 5T8, Canada.

Copyright @ 2013 Adriana Raquel Díaz.

All rights reserved. No part of this work may be reproduced in any form or by any means without permission in writing from the publisher.

The policy of Multilingual Matters/Channel View Publications is to use papers that are natural, renewable and recyclable products, made from wood grown in sustainable forests. In the manufacturing process of our books, and to further support our policy, preference is given to printers that have FSC and PEFC Chain of Custody certification. The FSC and/or PEFC logos will appear on those books where full certification has been granted to the printer concerned.

Typeset by Techset Composition India (P) Ltd., Bangalore and Chennai, India. Printed and bound in Great Britain by Short Run Press Ltd. 